\title{
物体間の接触の安定性に関する評価
}

余永*1 吉川 恒 ${ }^{* 2}$

\section{Evaluation of Contact Stability between Objects}

\author{
Yong $\mathrm{Yu}^{* 1}$ and Tsuneo Yoshikawa ${ }^{* 2}$
}

\begin{abstract}
In assembly operations, there are various constraint states while a moving object is in contact with a fixed object. For different constraint states, the existent regions of contacting forces, geometrical constraints, possible object displacements, which can be expressed by polyhedral convex cones respectively, are different. We consider that the sizes of these regions are important characteristic of contact stability for planning assembly operations. This paper proposes an approach that can evaluate the sizes of these regions. Based on this approach, the magnitudes of form constraint region, applicable equilibrating force region and admissible displacement region are defined to evaluate the contact stability of constraint state. Then, their applications to planning of assembly tasks are discussed.
\end{abstract}

Key Words: Contact Stability, Magnitude of Form Constraint Region, Magnitude of Applicable Equilibrating Force Region, Magnitude of Admissible Displacement Region, Assembly Planning

\section{1. 緒言}

組立などの作業において，物体の位置姿勢や制御動作などの 不確定性を減少させるために, 固定した環境に対象物体を接触 させて作業を行う。作業中，接触によって対象物の一部の運動 方向がある領域に拘束され，この領域によって作業に関連する 一部の不確定性が吸収される。このとき，接触を維持するため にロボットからの可能な押し付け力の領域が存在するので[13], 領域内の操作力を対象物に加えれば, 現接触を維持しながら操 作を行うことが保証できる.

一般に, 物体はそれと接触した環境から片側拘束を受けるが, 接触の状態により物体の可能な運動も異なってくる. Ohwovoriole ら [1] は片側拘束を一組の不等式方程式によって表し, そ れに基づき screw theoryを発展させ拘束物体の運動を解析して いる. Hirai ら [2]は片側拘束不等式の組をシステム的に取り扱 うために凸多面錐理論を導入し，拘束物体の運動学的静力的解 析を行っている. 他にも, 凸多面錐理論は数多くの物体拘束に 関する研究に適用されている。例えば, 比留川 [8]らは物体間の 幾何拘束条件を求める一般的手法の研究を行っている. Trinkle ら [3]は，ロボット指と環境から拘束を受けた物体の運動を分析 し，滑り接触を伴う dexterous object manipulation の計画方 法を提案している. 張ら [9]は把持物体と指リンク間の接触関係

原稿受付 1999 年 10 月 28 日

${ }^{* 1}$ 鹿児島大学工学部

$* 2$ 京都大学大学院工学研究科

${ }^{* 1}$ Faculty of Engineering, Kagoshima University

${ }^{* 2}$ Graduated School of Engineering, Kyoto University
に注目し，不完全な接触をもつ把持の力学的解析を行っている. また, Schimmels ら [4] は fixels と接触した物体の運動を考察 し, force-guided な組立手法を提案している.

組立作業を確実に行うためには，操作の安定性が重要である。 対象物への拘束の領域が大きいほど作業に関連する不確定性が 吸収されて物体間の接触や接触の維持などがより実現しやすく, 操作がより安定に行えると考えられる。したがって，操作途中 でおのおのの可能な拘束の内，なるべく大きい領域をもつ拘束 を選ぶことが望ましい，筆者らは，その領域の度合を領域の所 在する空間の次元数で評価することを考えて, 接触状態におけ る拘束度拈よび二種類の自由度を定義し，それに基づく組立操 作の自動計画法を提案した [11] [12]. しかしながら，そこでは 同次元数の領域に対してそれ以上の詳しい評価を行っていない．

本論文では，対象物を環境に押し付けて接触させた場合，一 定の領域内の外力が働いたときに環境拘束からの接触力の自動 的な変化により対抗力を生成して現接触を維持するための, 物 体間の接触の安定性を評価する，拘束の領域が大きいほど接触 が安定になり得るので, 領域の大きさに着目すれば接触の安定 性を評価できると考える。 そこで本論文では, 単位超球を導入 してその上で拘束方向などの領域を表現し, 単位超球面上の領 域に対応する面積により, 領域の大きさを評価する方法を提案 する.まず，接触により環境から拘束を受ける対象物の可能微 小変位の集合, 対象物への形態拘束方向の集合および環境への 押し付け力の集合について述へ，接触物体間の運動学的力学的 関係を記述する。ついで, 単位超球面上において各集合の領域 を表現し，対応する超球面積により領域大きさの評価指標を提 案する。 そして，その組立作業計画への応用について述べる。 
以下本論文では，すべての物体が多面体かつ剛体であり，物 体間の摩擦がクーロン摩擦であり，また，物体運動が準静的に 解析できるという仮定のもとで議論する.

\section{2. 接触物体間の運動学的力学的関係の記述}

本章では, 物体間の接触の安定性を検討するための基として, 接触状態における対象物の可能微小変位の集合，対象物への形 態拘束方向の集合および環境への押し付け力の集合について記 述する。

\section{1 接触状態における対象物の可能微小変位の集合}

対象物の位置 $\boldsymbol{x}$ と姿勢 $\boldsymbol{\theta}$ を合わせたものを $m$ 次元配位 $\boldsymbol{q}$ で表し, その微小変位 $\Delta \boldsymbol{x}$ と $\Delta \boldsymbol{\theta}$ を合わせたものを $m$ 次元微 小変位 $\Delta \boldsymbol{q}$ で表す. $m$ は三次元空間内運動の場合には $m=6$ $(\boldsymbol{x}, \boldsymbol{\theta}, \Delta \boldsymbol{x}, \Delta \boldsymbol{\theta}$ は三次元ベクトル), 平面内運動の場合には $m=3(\boldsymbol{x}, \boldsymbol{\Delta} \boldsymbol{x}$ は二次元, $\boldsymbol{\theta}, \boldsymbol{\Delta} \boldsymbol{\theta}$ は一次元ベクトル $)$ とする. 環境の中の一つの配位において対象物が取り得る微小変位の寸 べてからなる集合は対象物の可能微小変位集合である。ここに， $\Delta \boldsymbol{\theta}$ は $\boldsymbol{\theta}$ の微小量ではなく, 微小回転変位を大きさに持つ回転 軸方向のベクトルを表すが，便宜上 $\Delta \boldsymbol{\theta}$ の記号を用いる.

組立作業において物体どうしを接触させる場合，接触してい る面分，稜線，頂点の組み合わせは，組立の過程において変化 する。このような組み合わせは接触状態と呼ばれる $[2]$. 一般に， 接触部分の内部で摩擦係数が一様であれば多面体のすべての接 触は点接触で表される。 そして各点の接触は非凸接触と凸接触 に分けられる [11]．凸接触は不安定な接触である [12] ので，以 下では点接触はすべて非凸接触であるとする。

対象物と環境がある接触点 $i$ で一点接触する場合, 対象物の 変位可能な領域は次式を満たす微小変位からなる空間となる。

$$
\boldsymbol{n}_{i}^{T} \boldsymbol{W}_{i}^{T} \Delta \boldsymbol{q} \geq 0
$$

ここで， $\boldsymbol{n}_{i}$ は接触点 $i$ における環境の外向き（対象物の内向 き）単位法線べクトルを表し, $\boldsymbol{W}_{i}=\left[\begin{array}{ll}\boldsymbol{I}_{3 \mathrm{or} 2} & {\left[\boldsymbol{r}_{i} \times\right]^{T}}\end{array}\right]^{T} \in$ $\boldsymbol{R}^{m \times(3 \mathrm{or} 2)}$ である。また, $\boldsymbol{r}_{i}$ は対象物の代表点から接触点まで の位置べクトルを表し， $\left[\boldsymbol{r}_{i} \times\right]$ は $\left[\boldsymbol{r}_{i} \times\right] \boldsymbol{n}_{i} \triangleq \boldsymbol{r}_{i} \times \boldsymbol{n}_{i}$ で定義さ れる歪対称行列であり， $\boldsymbol{I}_{3 \mathrm{or} 2}$ は三か二次元の単位行列である.

多点接触の場合，対象物の可能微小変位集合は各接触点の可 能変位空間の積として，次のような凸多面錐の形で表現できる.

$$
\begin{aligned}
& \Delta Q \triangleq\left\{\Delta q \mid T_{c} \Delta q \geq \mathbf{0}\right\} \\
& \boldsymbol{T}_{c} \triangleq\left[\begin{array}{llll}
\boldsymbol{W}_{1} \boldsymbol{n}_{1} & \boldsymbol{W}_{2} \boldsymbol{n}_{2} & \cdots & \boldsymbol{W}_{n} \boldsymbol{n}_{n}
\end{array}\right]^{T} \in \boldsymbol{R}^{n \times m}
\end{aligned}
$$

ここで，0 はすべての要素がゼロであるべクトルを表す． $\boldsymbol{T}_{c}$ は 拘束行列と呼ばれ $[11], n$ は接触点の数である。式 $(2)$ を満た す $\Delta \boldsymbol{q}$ の集合はその解空間によって書き換えることもできる [7].

$$
\Delta \boldsymbol{Q} \triangleq\left\{\Delta \boldsymbol{q} \mid \Delta \boldsymbol{q}=\boldsymbol{H}_{c} \boldsymbol{k}_{c}, \quad \boldsymbol{k}_{c} \geq \mathbf{0}\right\}
$$

ただし， $\boldsymbol{H}_{c}$ は $\Delta \boldsymbol{q}$ の解集合を張った $\operatorname{span}$ ベクトルからなる 行列であり， $\boldsymbol{k}_{*}$ は各 spanベクトルの大きさに関する係数べク トルを表す．例えば Fig. 1 に示すような平面内運動の場合を考 えると, その可能変位の集合は Fig. 2 のようになっている.

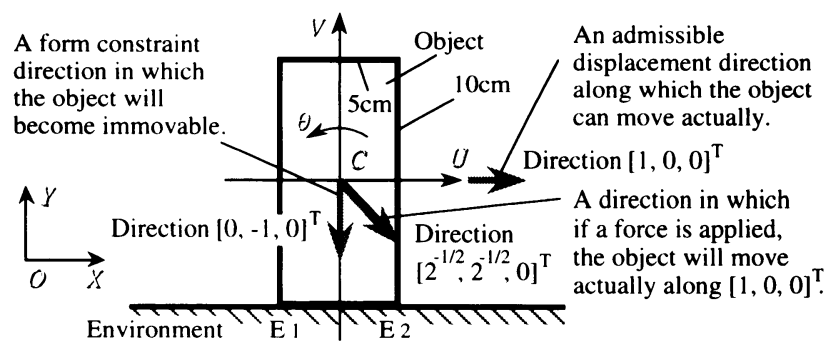

Fig. 1 Example of a contact state

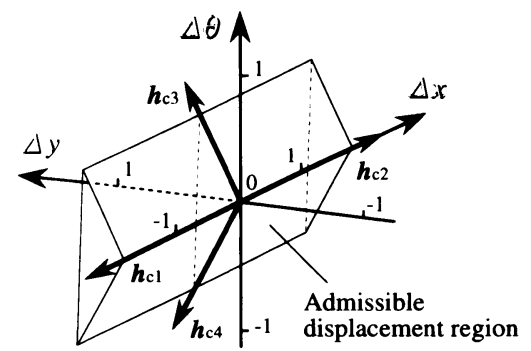

Fig. 2 Example of a possible displacement space

\section{2 接触状態における対象物への形態拘束方向の集合}

対象物と環境が接触するとき，上述した可能変位方向と違っ て，対象物が環境からの幾何学的拘束を受けて完全に動けなくな る方向が存在する．本論文では，このような方向を $\boldsymbol{g}\left(=\left[\Delta \boldsymbol{x}_{g}^{T}\right.\right.$, $\left.\left.\Delta \boldsymbol{\theta}_{g}^{T}\right]^{T} \in \boldsymbol{R}^{m},\|\boldsymbol{g}\|=1\right)$ と表し，これを対象物への形態拘束 方向と呼ぶことにする。ただし， $\Delta \boldsymbol{x}_{g}$ と $\Delta \boldsymbol{\theta}_{g}$ はそれぞれ微小 位置変位方向と微小回転变位方向における形態拘束方向 $\boldsymbol{g}$ の成 分を表す。この定義から，対象物のすべての運動方向が形態拘 束方向となるとき, 対象物が Form Closure される [5] [10]こと になる。

対象物が形態拘束により動けないことは, 可能微小変位領域 内に形態拘束方向の成分が存在しないことを意味する。すなわ ち形態拘束方向と任意の可能変位との内積が負か零になるべき である. 式 (2)より, 形態拘束方向の集合は次式で求められる.

$$
\begin{aligned}
\boldsymbol{G} & \triangleq\left\{\boldsymbol{g} \mid \boldsymbol{g}=-\boldsymbol{T}_{c}^{T} \boldsymbol{k}_{E} /\left\|-\boldsymbol{T}_{c}^{T} \boldsymbol{k}_{E}\right\|, \quad \boldsymbol{k}_{E} \geq \mathbf{0}\right\} \\
\boldsymbol{k}_{E} & \triangleq\left[\begin{array}{llll}
k_{1}^{E} & k_{2}^{E} & \cdots & k_{n}^{E}
\end{array}\right]^{T} \in \boldsymbol{R}^{n}
\end{aligned}
$$

これは，大きさが 1 の単位べクトルからなる凸多面錐であり， 空間の各要素が方向のみをもつことを意味する.

対象物が環境と摩擦なし接触するとき, 形態拘束方向の領域 へ力を加えると対象物が元のままで動けないが，形態拘束方向 領域と可能微小変位領域の間の空間に力を加えると, 対象物が 環境の幾何学的拘束を受けながら可能変位の方向へ動いてしま う. 例えば, Fig. 1 において接触を摩擦なしのものとする場合, 形態拘束方向 $[0,-1,0]^{T}$ へ力を加えるとき, 対象物は静止の ままとなるが，もし方向 $\left[2^{-1 / 2},-2^{-1 / 2}, 0\right]^{T}$ へ力を加えると， 対象物が環境の拘束によって可能変位方向 $[1,0,0]^{T}$ 一移動し てしまう。この例の形態拘束方向の集合を Fig. 3 に示す.

\section{3 接触状態における環境への押し付けカの集合}

対象物を環境に押し付けて静止させる（またはある変位方向 へ徐々に運動させる）ことを考え，ロボットの環境への押し付 


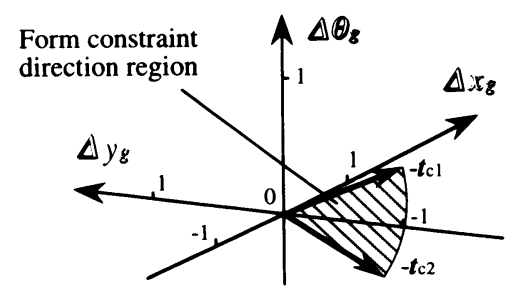

Fig. 3 Example of a form constraint direction space

け力の集合を示す.

接触状態において，ロボットにより対象物に力を加えるとき に，ある接触点での法線方向に環境反力の成分が存在すれば，こ の接触点では環境からの反力が発生し, そして摩擦力が発生し 得ると考えられる。押し付け力はこのような摩擦力を含む環境 反力と釣り合って，各接触点での接触を維持する [13].

まず，各点の $\boldsymbol{W}_{i} \boldsymbol{n}_{i}$ が島いに線形独立となる $n=\operatorname{rank} \boldsymbol{T}_{c}$ の 場合を考える. 対象物に加わる操作力の並進力成分 $f \in \boldsymbol{R}^{30 \mathrm{or} 2}$, 回転力成分 $\boldsymbol{\tau} \in \boldsymbol{R}^{3 \text { or1 }}$ を合わせて $\boldsymbol{w} \triangleq\left[\begin{array}{ll}\boldsymbol{f}^{T} & \boldsymbol{\tau}^{T}\end{array}\right]^{T} \in \boldsymbol{R}^{m}$ と する. 対象物と環境が $n$ 点で接触しているとき, 各点において 同時に環境からの反力を発生させるための操作力 $\boldsymbol{w}_{\eta}$ の集合は

$$
\begin{aligned}
\boldsymbol{F}_{\eta}=\left\{\boldsymbol{w}_{\eta} \mid \boldsymbol{w}_{\eta}=-\boldsymbol{T}_{c}^{T} \boldsymbol{k}+\boldsymbol{U} \check{\boldsymbol{k}}_{1}+(-\boldsymbol{U}) \check{\boldsymbol{k}}_{2},\right. \\
\left.\boldsymbol{k}>\mathbf{0}, \check{\boldsymbol{k}}_{1}, \check{\boldsymbol{k}}_{2} \geq \mathbf{0}\right\}(7)
\end{aligned}
$$

であり，凸多面錐の形となっている [13].ただし，U $\in$ $\boldsymbol{R}^{m \times(m-n)}$ は $\boldsymbol{T}_{c}$ の零空間の線形独立な単位ベクトルから作 られた対象物の自由変位方向に関する行列であり, $k \in \boldsymbol{R}^{n}$, $\check{\boldsymbol{k}}_{1}, \check{\boldsymbol{k}}_{2} \in \boldsymbol{R}^{(m-n)}$ である. $\boldsymbol{F}_{\eta}$ の要素の力が対象物を押したと きに必ずしも環境の反力と釣り合うという保証はない.

対象物か環境に押されたとき，摩擦条件により環境からの反 力はある範囲以内のみ存在可能である。クーロン摩擦円錐が， $m=3$ の場合には厳密的に $(v=2), m=6$ の場合には近似 的に $(v>2)$ 円錐と内接した $v$ 稜線の正凸多面錐で表現でき る [6]. 望みの対象物変位 $\Delta \boldsymbol{q}_{d}$ を与えたとき, 接触点 $i$ の局部 変位 $\Delta \boldsymbol{r}_{i}^{d}=\boldsymbol{W}_{i}^{T} \Delta \boldsymbol{q}_{\boldsymbol{d}}$ による接触点の静止，滑りまたは分離に 対応して, 環境からの可能な反力は次のように表される [13].

$$
\begin{aligned}
& \boldsymbol{f}_{i}^{E^{\prime}} \triangleq \sum_{l=1}^{v} k_{i l}^{E^{\prime}} \boldsymbol{c}_{i l}^{E^{\prime}}, \quad k_{i l}^{E^{\prime}} \geq 0, l=1,2, \cdots, v \\
& \left\{\begin{aligned}
1) \boldsymbol{c}_{i}^{E^{\prime}} & =\boldsymbol{c}_{i l}^{E} & \text { for } & \boldsymbol{n}_{i}^{T} \Delta \boldsymbol{r}_{i}^{d}=0 \text { and } \Delta \boldsymbol{r}_{i}^{d}=\mathbf{0} \\
k_{i l}^{E^{\prime}} & =k_{i l}^{E} & & \left(k_{i l}^{E}>0, l=1,2, \cdots, v\right) \\
2) \boldsymbol{c}_{i 1}^{E^{\prime}} & =\boldsymbol{c}_{i}^{D} & \text { for } & \boldsymbol{n}_{i}^{T} \Delta \boldsymbol{r}_{i}^{d}=0 \text { and } \Delta \boldsymbol{r}_{i}^{d} \neq \mathbf{0} \\
\boldsymbol{c}_{i l}^{E^{\prime}} & =\mathbf{0}(l \geq 2) & & \left(k_{i l}^{D} \geq 0, l=1,2, \cdots, v\right) \\
k_{i 1}^{E^{\prime}} & =k_{i}^{D} & & \\
k_{i l}^{E^{\prime}} & =0(l \geq 2) & & \\
3) \boldsymbol{c}_{i}^{E^{\prime}} & =\mathbf{0} & \text { for } & \boldsymbol{n}_{i}^{T} \Delta \boldsymbol{r}_{i}^{d}>0 \\
k_{i l}^{E^{\prime}} & =0 & & (l=1,2, \cdots, v)
\end{aligned}\right.
\end{aligned}
$$

ここで， $\boldsymbol{c}_{i l}^{E}$ は接触点における静止摩擦多面錐の稜線にそった 対象物内部に向く単位ベクトルであり, $k_{i l}^{E}$ は $\boldsymbol{c}_{i l}^{E}$ 方向の環 境反力の成分を表す。また，動摩擦係数 $\beta^{D}$ により， $\boldsymbol{c}_{i}^{D}=$

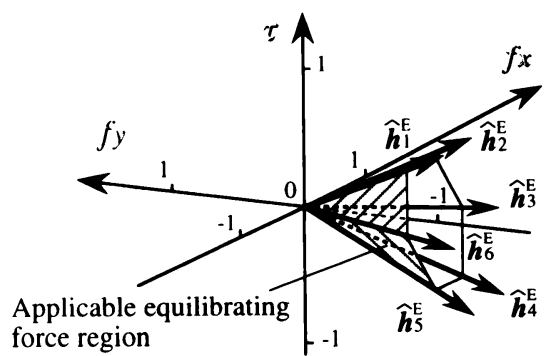

Fig. 4 Example of an applicable equilibrating force space

$\left(\boldsymbol{n}_{i}-\beta^{D} \Delta \boldsymbol{r}_{i}^{d} /\left\|\Delta \boldsymbol{r}_{i}^{d}\right\|\right) /\left(\left\|\boldsymbol{n}_{i}-\beta^{D} \Delta \boldsymbol{r}_{i}^{d} /\right\| \Delta \boldsymbol{r}_{i}^{d}\|\|\right)$ であり, $k_{i}^{D}$ は $\boldsymbol{c}_{i}^{D}$ 方向の環境反力の成分を表す。

このような環境側の可能な反力と釣り合うために，力集合

$$
\begin{gathered}
\overline{\boldsymbol{F}}_{E^{\prime}}=\left\{\overline{\boldsymbol{w}}_{E^{\prime}} \mid \overline{\boldsymbol{w}}_{E^{\prime}}=-\boldsymbol{H}_{E^{\prime}} \boldsymbol{k}_{E^{\prime}}, \quad \boldsymbol{k}_{E^{\prime}}>\mathbf{0}\right\} \\
\boldsymbol{H}_{E^{\prime}} \triangleq\left[\boldsymbol{W}_{1} \cdots \boldsymbol{W}_{n}\right] \boldsymbol{C}_{E^{\prime}} \in \boldsymbol{R}^{m \times v n} \\
\boldsymbol{C}_{E^{\prime}} \triangleq \operatorname{diag}\left[\left[\boldsymbol{c}_{11}^{E^{\prime}} \cdots \boldsymbol{c}_{1 v}^{E^{\prime}}\right], \cdots,\left[\boldsymbol{c}_{n 1}^{E_{1}^{\prime}} \cdots \boldsymbol{c}_{n v}^{E^{\prime}}\right]\right] \\
\quad \in \boldsymbol{R}^{(3 \text { or } 2) n \times v n} \\
\boldsymbol{k}_{E^{\prime}} \triangleq\left[k_{11}^{E^{\prime}} \cdots k_{1 v}^{E^{\prime}} \cdots k_{n 1}^{E^{\prime}} \cdots k_{n v}^{E^{\prime}}\right]^{T} \in \boldsymbol{R}^{v n}
\end{gathered}
$$

を満たした操作力 $\overline{\boldsymbol{w}}_{E^{\prime}}$ を対象物に加えるべきである.しかし， $\overline{\boldsymbol{F}}_{E^{\prime}}$ はクーロン摩擦により決められたものである. 実際に加え る可能な操作力は, 式 (7) の反力発生操作力集合 $\boldsymbol{F}_{\eta}$ に限定 される，したがって，環境への押し付け力の集合 $\widehat{\boldsymbol{F}}_{E^{\prime}}$ は，式 （7）と（9）により, 次式で表される凸多面錐となる [13].

$$
\widehat{\boldsymbol{F}}_{E^{\prime}}=\overline{\boldsymbol{F}}_{E^{\prime}} \cap \boldsymbol{F}_{\eta}=\left\{\widehat{\boldsymbol{H}}_{E^{\prime}} \widehat{\boldsymbol{k}}_{E^{\prime}} \mid \widehat{\boldsymbol{k}}_{E^{\prime}}>\mathbf{0}\right\}
$$

例えば，Fig. 1 に示した例の静止接触場合の環境への押し付 け力集合は Fig. 4 のようになっている. ただし, 対象物と環境 の接触部における静止摩擦係数を一様とし 0.5 にした。

各点の $\boldsymbol{W}_{i} \boldsymbol{n}_{i}$ が互いに線形独立でない $n>\operatorname{rank} \boldsymbol{T}_{c}$ の場合, 各点において同時に環境反力を発生させるのは実現困難となる が，その中の $\operatorname{rank} \boldsymbol{T}_{c}$ 点からの反力の同時発生を考える.

まず, $n$ 本の $\boldsymbol{W}_{i} \boldsymbol{n}_{i}$ からなる集合 $\left\{-\boldsymbol{T}_{c}^{T} \boldsymbol{k}, \boldsymbol{k}>\mathbf{0}\right\}$ は 集合 $\left\{-\boldsymbol{T}_{c j}^{T} \boldsymbol{k}_{j}, \boldsymbol{k}_{j}>\mathbf{0}\right\}, j=1,2, \cdots, u$ からなる和集合 $\bigcup_{j=1}^{u}\left\{-\boldsymbol{T}_{c j}^{T} \boldsymbol{k}_{j}, \boldsymbol{k}_{j}>\mathbf{0}\right\}$ と等価となることから, $u$ 個の $\boldsymbol{T}_{c j}$ が得られる.ただし, $\left\{-\boldsymbol{T}_{c j}^{T} \boldsymbol{k}_{j}, \boldsymbol{k}_{j}>\mathbf{0}\right\}$ は $n$ 本の $\boldsymbol{W}_{i} \boldsymbol{n}_{\boldsymbol{i}}$ の 中の任意の $\operatorname{rank} \boldsymbol{T}_{c}$ 本からなる $\operatorname{rank} \boldsymbol{T}_{c j}=\operatorname{rank} \boldsymbol{T}_{c}$ の集合と し，その数 $u$ は $u \leq{ }_{\left(\mathrm{rank} T_{c}\right)} C_{n}\left(\boldsymbol{W}_{i} \boldsymbol{n}_{i}\right.$ の組み合わせの数 $)$ で ある。一つの $\boldsymbol{T}_{c j}$ に含まれる各 $\boldsymbol{W}_{i} \boldsymbol{n}_{i}$ が互いに線形独立にな るので, 式 (7)，(9) と（13）を用いて，対応する押し付け力

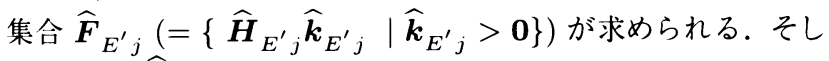
て $u$ 個の $\widehat{\boldsymbol{F}}_{E^{\prime}{ }_{j}}$ 加, 和集合

$$
\widehat{\boldsymbol{F}}_{E^{\prime}}=\bigcup_{j=1}^{u} \widehat{\boldsymbol{F}}_{E^{\prime} j}=\bigcup_{j=1}^{u}\left\{\widehat{\boldsymbol{H}}_{E^{\prime} j^{\prime}} \widehat{\boldsymbol{k}}_{E^{\prime} j} \mid \widehat{\boldsymbol{k}}_{E^{\prime} j}>\mathbf{0}\right\}
$$

が得られる。この集合は, $n$ 個の点のうちどこかの $\operatorname{rank} \boldsymbol{T}_{c}$ 個 の点において環境反力を同時に発生させるための押し付け力の 集合となる。ただし、凸多面錐の各 $\widehat{\boldsymbol{F}}_{E^{\prime} j}$ 少らなる和集合 $\widehat{\boldsymbol{F}}_{E^{\prime}}$ は凸多面錐とならない場合がある [7]. 


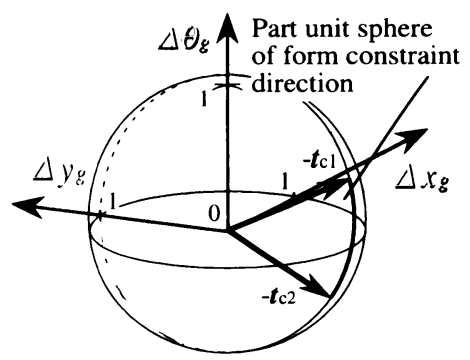

Fig. 5 Part unit sphere of form constraint direction

\section{3. 物体間の接触関係に関する諸集合の領域への評価}

上述した諸集合は凸多面錐を用いて記述することができ，集 合の存在領域の占める空間の次元数は分かる [11] [12]. しかし， 集合の領域が同次元数の全空間の何割を占めるかのは評価でき ない，本章では，単位超球体を導入して各集合の領域の表現方 法を述へ，領域がもつ単位超球面上の球面積により，領域の大 きさを評価する方法について議論する。

\section{1 単位超球面上における各集合の領域の表現}

本節では，凸多面錐空間における各要素の方向の存在領域を 反映できる単位超球体を導入して，単位超球面上において形態 拘束方向領域，押し付け力領域と可能微小変位領域を表現する。

まず，単位超球体上において形態拘束方向集合の領域の表現 を考える．2.2 節に記述したように，ある接触状態において，方 向性のみをもつ形態拘束方向 $\boldsymbol{g}(\|\boldsymbol{g}\|=1)$ の集合は次のように 表現される。

$$
\boldsymbol{G} \triangleq\left\{\boldsymbol{g} \mid \boldsymbol{g}=\frac{-\boldsymbol{T}_{c}^{T} \boldsymbol{k}_{E}}{\left\|-\boldsymbol{T}_{c}^{T} \boldsymbol{k}_{E}\right\|}, \quad \boldsymbol{k}_{E} \geq \mathbf{0}\right\}
$$

この集合は, $\left\{-\boldsymbol{T}_{c}^{T} \boldsymbol{k}_{E} \mid \boldsymbol{k}_{E} \geq \mathbf{0}\right\}$ の凸多面錐と $\operatorname{rank} \boldsymbol{T}_{c}(\leq m)$ 次元の単位超球体との共通集合であるので, 単位超球体の一部 分となっている。ここでは，これを形態拘束方向集合の部分単 位超球体と呼ぶことにし，この部分超球体によって集合の領域 を表す。この部分超球体の次元数は

$$
a_{g}=\operatorname{rank} \boldsymbol{T}_{c}, \quad\left(a_{g} \leq 6\right)
$$

となり，接触状態における拘束度にもなっている [11].

同様に, $n=\operatorname{rank} \boldsymbol{T}_{c}$ の場合, 式 (13) 加単位超球体を用い て, $\left\|\widehat{\boldsymbol{w}}_{E}\right\|=1$ を満足するようなすべての押し付け力 $\widehat{\boldsymbol{w}}_{E}$ の集 合, つまり押し付け力集合の部分単位超球体 $\widehat{\boldsymbol{F}}_{E^{\prime}}^{\sharp}$ は, 式 (15) と 同様な形で記述できる. その次元数は $a_{w}=\operatorname{rank} \widehat{\boldsymbol{H}}_{E^{\prime}}\left(a_{w} \leq 6\right)$ となる.ただし, $n>\operatorname{rank} \boldsymbol{T}_{c}$ の場合の $\widehat{\boldsymbol{F}}_{E^{\prime}}^{\sharp}$ は式 (14)により

$$
\widehat{\boldsymbol{F}}_{E^{\prime}}^{\sharp}=\bigcup_{j=1}^{u}\left\{\widehat{\boldsymbol{w}}_{E^{\prime}}^{\sharp} \mid \widehat{\boldsymbol{w}}_{E^{\prime}}^{\sharp}=\frac{\widehat{\boldsymbol{H}}_{E^{\prime} j} \widehat{\boldsymbol{k}}_{E^{\prime} j}}{\left\|\widehat{\boldsymbol{H}}_{E^{\prime} j} \widehat{\boldsymbol{k}}_{E^{\prime} j}\right\|}, \widehat{\boldsymbol{k}}_{E^{\prime} j}>\mathbf{0}\right\}
$$

と記述され，その次元数 $a_{w}$ は $a_{w}=\max \left[\operatorname{rank} \widehat{\boldsymbol{H}}_{E^{\prime} 1}, \cdots\right.$, $\left.\operatorname{rank} \widehat{\boldsymbol{H}}_{E^{\prime} u}\right]\left(a_{w} \leq 6\right)$ となる.

集合 $\widehat{\boldsymbol{F}}_{E^{\prime}}$ が凸多面錐となる場合，超球体 $\widehat{\boldsymbol{F}}_{E^{\prime}}^{\sharp}$ の球面は凸超 球面である. 式（13）の部分単位超球体の球面部分の中心点は

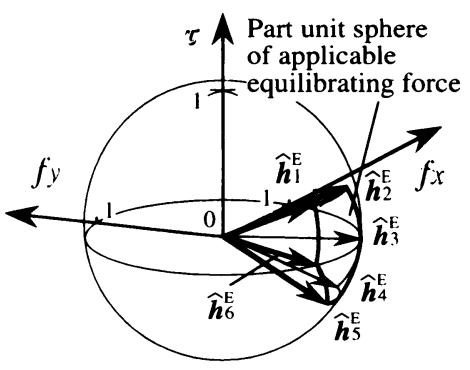

Fig. 6 Part unit sphere of applicable equilibrating force

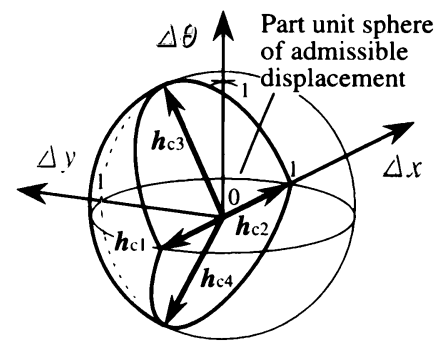

Fig. 7 Part unit sphere of admissible displacement

式（18）として求まる.

$$
\widehat{\boldsymbol{w}}_{E^{\prime} C}^{\sharp} \triangleq \frac{\widehat{\boldsymbol{H}}_{E^{\prime}} \widehat{\boldsymbol{k}}_{E^{\prime}}}{\left\|\widehat{\boldsymbol{H}}_{E^{\prime}} \widehat{\boldsymbol{k}}_{E^{\prime}}\right\|}, \quad\left\|\widehat{\boldsymbol{h}}_{i}^{E^{\prime}} \widehat{k}_{i}^{E^{\prime}}\right\|=1, \widehat{\boldsymbol{k}}_{E^{\prime}}>\mathbf{0}
$$

ただし $\widehat{\boldsymbol{h}}_{i}^{E^{\prime}}$ と $\widehat{k}_{i}^{E^{\prime}}$ はそれぞれ $\widehat{\boldsymbol{H}}_{E^{\prime}}$ と $\widehat{\boldsymbol{k}}_{E^{\prime}}$ の要素である。対 象物を環境に押し付けて接触を維持させるときに，外乱などの 不確定な要素によって作用力方向の変動が生じると, 接触は変 化する可能性がある．凸超球面中心の方向やその近傍に押し付 け力を加えれば, 変動後の力方向が引き続き $\widehat{\boldsymbol{F}}_{E^{\prime}}$ の領域内に 存在する可能性がより高くなり, 接触が維持しやすくなる.

また，単位超球体を用いて，式（4）の $\|\Delta \boldsymbol{q}\|=1$ を満足す るような可能微小变位 $\Delta \boldsymbol{q}$ から, 対象物可能微小変位集合の部 分単位超球体 $\Delta Q^{\sharp}$ も式 (15) と同様な形で記述できる。 その 次元数は $a_{q}=\operatorname{rank} \boldsymbol{H}_{c}\left(a_{c} \leq 6\right)$ である. その球面中心は式 （18）のような方法で得られる。.これは対象物の全接触点を同時 に環境から離脱させるためのより容易な変位方向である。

例として，Fig. 1 に示した接触状態における形態拘束方向集 合, 押し付け力集合と可能微小变位集合の部分単位超球体を, そ れぞれFig. 5, Fig. 6 と Fig. 7 に示す.

\section{2 各集合の存在領域の評価指標}

部分単位超球体の球面積により，各集合の存在領域を評価す る指標を考える。本論文では，全単位超球体における部分単位 超球体の割合を領域の評価指標とする。

まず, 形態拘束方向領域の評価指標 $E_{a_{g}}^{C}$ を次に定義する.

$$
\begin{aligned}
E_{a_{g}}^{C} & \triangleq \frac{\int \cdots \int_{\boldsymbol{D}_{a_{g}}^{C}} d A_{a_{g}}^{C}}{\boldsymbol{S}_{a_{g}}} \\
\boldsymbol{D}_{a_{g}}^{C} & =\left\{-\boldsymbol{T}_{c}^{T} \boldsymbol{k}_{E} /\left\|-\boldsymbol{T}_{c}^{T} \boldsymbol{k}_{E}\right\| \quad \boldsymbol{k}_{E} \geq \mathbf{0}\right\}
\end{aligned}
$$

ここで, $\int \cdots \int_{D_{a_{g}}^{C}} d A_{a_{g}}^{C}$ は形態拘束方向部分単位超球体の球 
面積, $d A_{a_{g}}^{C}$ はその球面積要素である. $\boldsymbol{S}_{*}$ は* 次元単位超球体 の全球面積である。一次元単位球体の全球面積は $S_{1}=2$, その 半球面積は 1 とする. また, 二次元から六次元までの単位超球 体の全球面積はそれぞれ $\boldsymbol{S}_{2}=2 \pi, \boldsymbol{S}_{3}=4 \pi, \boldsymbol{S}_{4}=2 \pi^{2}, \boldsymbol{S}_{5}=$ $8 \pi^{2} / 3, \boldsymbol{S}_{6}=\pi^{3}$ となる. $\int \cdots \int_{\boldsymbol{D}_{a_{g}}^{C}} d A_{a_{g}}^{C}$ は数值積分方法のよ うな計算で求められる。 まず，形状一定の “cubic” 単元を用い て球面積要素を近似的に表現し, 単位超球体の全球面において “cubic” 単元の分割をとる. 次に, これらの単元が領域 $\boldsymbol{D}_{a_{g}}^{C}$ を 満たすかどうかを判別する，最後に， $D_{a_{g}}^{C}$ を満たした各単元の 球面積の和を取って部分超球体の球面皘とする. なお, 対象物 がある方向の正負両側には形態拘束を受けて別のある方向の正 負両側へは自由運動できるような場合, $\boldsymbol{W}_{i} \boldsymbol{n}_{i}$ の方向上の計算 誤差などにより $\operatorname{rank} \boldsymbol{T}_{c}$ が正しく求まらない可能性がある。計 算上などこの点を注意されたい。

形態拘束方向領域の評価指標が大きけ机ば，作業中の不確定 性を吸収する可能性が大きくなり，作業もより安定に行える，式 (19)より, $E_{a_{g}}^{C}=0$ は $a_{g}$ 次元空間において対象物への形態 拘束方向が存在しないこと, $E_{a_{g}}^{C}=1$ はその空間のすべての方 向に形態拘束が存在することを表す。例えば, $E_{6}^{C}=1$ は六次 元空間において対象物が form closure されたことを表す。

同様に, 押し付け力の部分単位超球体の球面積により, 加え ることが可能な押し付け力の領域への評価，つまり押し付け力 領域の評価指標 $E_{a_{w}}^{M I}$ も式 (19) のような形で定義できる。この 評価指標が大きければ，不確定さをもつ外乱などを受けたとき， 押し付け力と外乱からなる合力を収める領域も大きくなる。す なわち, 現接触状態の可維持さが大きくなると考えられる。 た だし $n>\operatorname{rank} \boldsymbol{T}_{c}$ の場合, 式 (17) によりその領域 $\boldsymbol{D}_{a_{w}}^{M}$ を

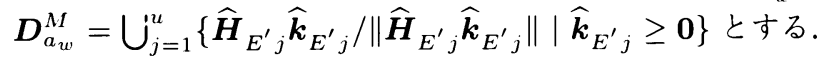

また，可能変位の部分単位超球体の球面積により，可能微小 変位領域の評価指標 $E_{a_{q}}^{S}$ も式（19）のような形で定義できる. 評価指標が大きければ，作業途中で不確定的な要素により対象 物を予想外のところに変位されてしまう可能性も大きくなる。

\section{4. 組立作業計画への応用}

\section{1 組立操作計画への評価}

ロボットを用いた組立操作とは, 対象物を指定環境と接触さ せながら適当な接触面によって案内し, 初期の接触状態から目 標とする接触状態に持っていく過程である。この過程は, いく つかの接触状態遷移の系列で表示できる，異なる系列に応じて， 経由した接触状態の数, および状態遷移実現の難易の程度が異 なる. 文献 [11] [12] では, 各接触状態の形態拘束空間や可能微 小変位空間の次元の変化によって,いくつかの系列の中から, ど の系列を選べばよいかという組立操作の自動計画方法を提案し た。しかし，そこでは同次元空間の間の差の影響についてはま だ十分に考察していなかった。. 以下では, 文献 [11] [12]の方法 で求めた同評価値の結果に対して, 前述した評価指標を用いて さらに評価し，より合理的な組立操作計画を求める。

文献 [11]では, 環境と接触した対象物がどの次元の形態拘束を 受けているかを表すために，接触状態の拘束度 $c \triangleq \operatorname{rank} \boldsymbol{T}_{c}(0 \leq$ $c \leq m)$ を定義した. 本論文では, さらに同次元の空間内の差
を示すために，形態拘束方向領域の評価指標を定義した。この 評価指標を用いて文献 [11] [12]による方法では同評価値となる $N$ 本の状態遷移系列を評価するために，まず同じ次元形態拘束 方向空間（つまり同じ拘束度）の状態を同数にもつ系列を次の 手順で選び出す。

\section{評価手順 $(\mathbf{A})$}

手順 1 まず, 状態遷移系列 $p_{s}, s=1,2, \cdots, N$ のうち, $m$ 拘束度をもつ状態の数が一番多くなる系列 $p_{c_{m}}$ を選び出す。

手順 2 続いて, 選び出された系列 $p_{c_{m}}$ のうち, $m-1$ 拘束 度をもつ状態の数が一番多くなる系列 $p_{c_{m-1}}$ を選び出す.

手順 3 このように，拘束度を一つずつ減らして残された系列 を調べていくと，最後に選び出された系列 $p_{c_{2}}$ のうち, 1 拘束度をもつ状態の数が一番多くなる系列 $p_{c_{1}}$ を選び出す.

選ばれた系列 $p_{c_{1}}$ は， $N$ 本の状態遷移系列のうちで，より大 きな拘束度の接触状態を最も多くもつ系列である。一般に，対 象物が環境からの形態拘束を受けながら次の接触状態へ遷移し ていくとき，受けた形態拘束の程度が大きいほど外乱などの不 確定性が吸収されやすいので，状態の遷移も実現しやすい。よっ て, 系列 $p_{c_{1}}$ はより合理の状態遷移系列となる。ここでは, 系 列 $p_{s}, s=1,2, \cdots, N$ 中の $p_{c_{1}}$ 以外のものを続いて調べずに 取り除くことにする.

便宜上，すべての $p_{c_{1}}$ の集合 $P_{c}$ を次のように記述する.

$$
P_{c} \triangleq\left\{p_{c_{1}}, c_{1}=1,2, \cdots, N_{c}\right\}
$$

ただし $N_{c}$ は系列 $p_{c_{1}}$ の数である. $N_{c}$ が 1 となる場合この系 列は最も合理のものとみなされるが， $N_{c}$ が複数となる場合こ れらの系列に対してはさらなる評価が望ましい.

\section{1 .1 評価指標を用いた評価}

二つの接触状態は拘束度が等しくなっても，大きな形態拘束 方向領域をもつ状態はより多くの方向の不確かな外乱に抵抗で きるので，より安定的な接触になる. そこで, 形態拘束方向領 域評価指標を用いて $P_{c}$ の中からもっと合理の系列を選択する.

\section{評価手順 (B)}

手順 1 まず, $N_{c}$ 本の状態遷移系列のうち, $m$ 拘束度をもつ 状態の形態拘束方向領域評価指標の和が一番大きくなる系 列 $p_{g_{m}}$ を選び出す.

手順 2 続いて, 選び出された系列 $p_{g_{m}}$ のうち, $m-1$ 拘束 度をもつ状態の形態拘束方向領域評価指標の和が一番大き くなる系列 $p_{g_{m-1}}$ を選び出す.

手順 3 このように, 拘束度を一つずつ減らして残された系列 を調べていくと, 最後に選び出された系列 $p_{g_{2}}$ のうち, 1 拘束度をもつ状態の形態拘束方向領域評価指標の和が一番 大きくなる系列 $p_{g_{1}}$ を選び出す.

この系列 $p_{g_{1}}$ は，より大きな形態拘束方向領域の状態を最も 多くもつので，より合理の系列である。ここで $p_{g_{1}}$ の集合を

$$
P_{g} \triangleq\left\{p_{g_{1}}, g_{1}=1,2, \cdots, N_{g}\right\}
$$

のように記述し, $N_{g}$ を $p_{g_{1}}$ の数とする.

系列 $p_{g_{1}}$ が複数個存在するときには, 接触部の摩擦の影響 を考慮に入れて, さらにより大きな押し付け力領域をもつ系列 
を選ぶ。このために，手順 (B)において，形態拘束方向領域評 価指標の代わりに押し付け力領域評価指標を用いて各系列 $p_{g_{1}}$, $g_{1}=1,2, \cdots, N_{g}$ を評価すれば，より大きな押し付け力領域の 接触状態を最も多くもつ系列 $p_{f_{1}}$ の集合

$$
P_{f} \triangleq\left\{p_{f_{1}}, f_{1}=1,2, \cdots, N_{f}\right\}
$$

が得られる。ただし， $N_{f}$ は系列 $p_{f_{1}}$ の数である。また，静止 接触および滑り接触に対応して, 接触状態の押し付け力領域が 異なるので, 各系列の接触状態の接触がともに静止接触あるい は滑り接触でなければ，互いに比較することができない.

なお，各系列の初期状態または目標状態は共同なので上述し た手順で調べるときに省かれる。

\subsection{2 組立操作計画への応用例}

平面内運動 $(m=3)$ において Fig. 8 のような例を考える. Fig. 8 に示した四つの接触状態遷移系列 $p_{s}, s=1,2,3,4$ は文 献 [11] [12] の方法では同じ評価值となる結果である．評価手順 (A) より, 接触状態拘束度で評価すると, $P_{c}=\left\{p_{c_{1}}, c_{1}=1\right.$, $2,3,4\}$ のように，四つの系列には同等な評価結果が得られる. この結果に基づいて, 形態拘束方向領域評価指標で評価して, もっと合理的な状態遷移系列を求める.

初期状態および目標状態を除いて, 各拘束度 $(c=0,1,2,3)$ に対応する形態拘束方向領域評価指標の和は, 式 (19)によ って系列 (1) の場合 $G_{01}=0, G_{11}=E_{11}^{G b}=0.50, G_{21}=$ $E_{21}^{G c}=0.25, G_{31}=0$, 系列 (2) の場合 $G_{02}=0, G_{12}=$ $E_{12}^{G b}=0.50, G_{22}=E_{22}^{G c}=0.35, G_{32}=0$, 系列 $(3)$ の場合 $G_{03}=0, G_{13}=E_{13}^{G b}=0.50, G_{23}=E_{23}^{G c}=0.30, G_{33}=0$, 系列 (4) の場合 $G_{04}=0, G_{14}=E_{14}^{G b}=0.50, G_{24}=E_{24}^{G c}=$ $0.30, G_{34}=0$ となっている. 拘束度 $c=2$ のとき, 系列 $(2)$ の 評価指標和 $G_{22}=0.35$ は一番大きくなるが，その他の拘束度 に関しては，各系列の評価指標の和が同じである。よって，評 価手順 $(\mathrm{B})$ から系列集合 $P_{g}=\left\{p_{g_{1}}=p_{2}\right\}$ が得られ, 系列 $(2)$
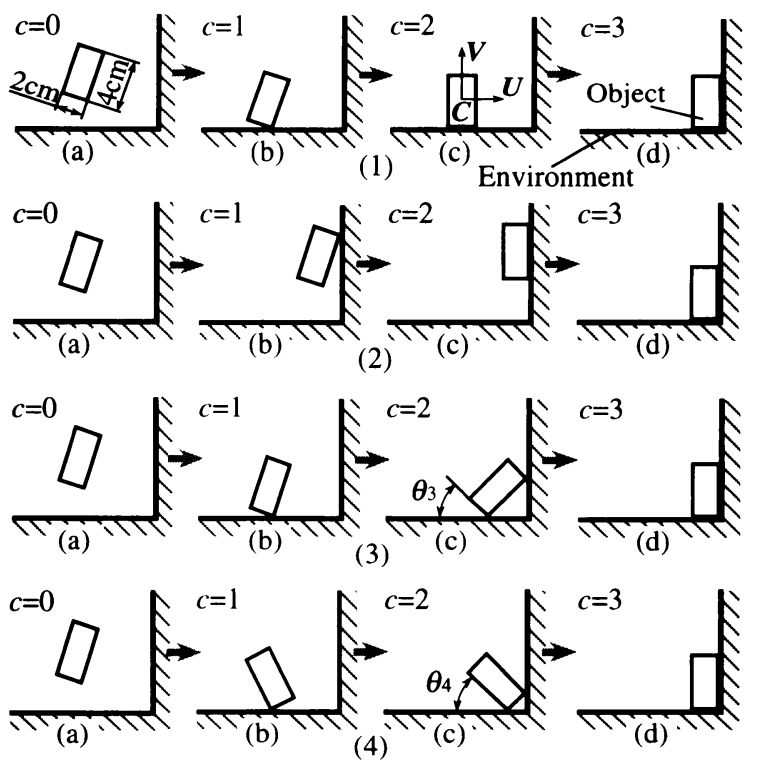

Fig. 8 Contact state transition paths from [11] [12]
が最も合理的な経路として選ばれた。

さらに, 系列 (3) と (4)のみに注目して考える。この場合, 形態拘束方向領域の評価指標によると, 両系列の評価值は等し い.そこで，さらに押し付け力領域評価指標を用いれば，両系 列を見分けることができる。ここで $\theta_{3}=\theta_{4}=45^{\circ}$, 静止摩擦 係数を 0.5 , 動摩擦係数を 0.33 とする. 初期状態および目標状 態を除いて, 拘束度 $c=2$ に対応する押し付け力領域評価指標 の和は静止するとき $F_{23}=E_{23}^{F b}=0.25, F_{24}=E_{24}^{F b}=0.10$ (三次元部分単位球) となり, 滑るとき $F_{23}=E_{23}^{F b}=0.25$, $F_{24}=E_{24}^{F b}=0.19$ (二次元部分単位球) となっている.これは, 系列 (3) の方は摩擦力によって回転力方向への抵抗がより大き く発生し得るためである.その他の拘束度に対しては, 両系列 の評価指標の和が等しい. したがって，仮に系列 (3) と (4)の みを比べれば，押し付け力領域が相対的に大きくなる系列 (3) の方がより適当となり， $P_{f}=\left\{p_{f_{1}}=p_{3}\right\}$ が選ばれる。これら の結果は直感にかなったものと考えられる。

\section{2 対象物上の把持位置の評価}

各指の把持位置および指力の方向（把持点の摩擦条件を満た した）を与えるとき，各指力の大きさを適当に変化させると，指 力の合力は一定の領域内で変動する．押し付け力の領域と指力 合力の領域の共通領域において, 指力の合力が加われば, 対象 物は確実に環境に押し付けられる。この共通領域（つまり実現 可能な押し付け力の領域）は，対象物上の異なる把持位置によっ て変化する. 指力の制御誤差などの不確定性を考慮に入れると， 共通領域が大きければ大きいほど，対象物と環境との安定的な 接触はより実現しやすい。ここではこの領域の大きさを用いて， 対象物を環境に押し付けるための把持位置を評価する.

\section{2 .1 指の把持で実現可能な環境への押し付け力の集合}

ロボット指が対象物を把持し, 把持点 $r$ での指力を $\boldsymbol{f}_{r}$ とす る. 各点の指力 $\boldsymbol{f}_{r}, r=1,2, \cdots, M$ からなる合力 $\boldsymbol{t}_{f}$ が

$$
\begin{aligned}
\boldsymbol{t}_{f} & =\boldsymbol{W}_{f}^{T} \boldsymbol{f} \\
\boldsymbol{f} & \triangleq\left[\begin{array}{lll}
\boldsymbol{f}_{1}^{T} & \cdots & \boldsymbol{f}_{M}^{T}
\end{array}\right]^{T} \in \boldsymbol{R}^{(3 \mathrm{or} 2) M} \\
\boldsymbol{W}_{f} & \triangleq\left[\begin{array}{llll}
\boldsymbol{W}_{f 1}^{T} & \cdots & \boldsymbol{W}_{f M I}^{T}
\end{array}\right]^{T} \in \boldsymbol{R}^{(3 \circ 2) M \times(6 \mathrm{or} 3)}(26)
\end{aligned}
$$

のようになる. 指力の方向 $\overline{\boldsymbol{f}}_{r}$ を与え, 指力 $\boldsymbol{f}_{r}=\overline{\boldsymbol{f}}_{r} k_{f r}$ と表 すと, 対応する合力集合 $\boldsymbol{T}_{f}$ は次のような凸多面錐で表される.

$$
\begin{aligned}
\boldsymbol{T}_{f} & =\left\{\boldsymbol{t}_{f} \mid \boldsymbol{t}_{f}=\boldsymbol{W}_{f}^{T} \overline{\boldsymbol{f}} \boldsymbol{k}_{f}, \quad \boldsymbol{k}_{f} \geq \mathbf{0}\right\} \\
\overline{\boldsymbol{f}} & \triangleq \operatorname{diag}\left[\overline{\boldsymbol{f}}_{1}, \cdots, \overline{\boldsymbol{f}}_{M}\right] \in \boldsymbol{R}^{(3 \circ \mathrm{or} 2) M \times M} \\
\boldsymbol{k}_{f} & \triangleq\left[\begin{array}{lll}
k_{f 1} & \cdots & k_{f M}
\end{array}\right]^{T} \in \boldsymbol{R}^{M}
\end{aligned}
$$

ここに $k_{f r}(>0)$ は指力の大きさを表す. 指力の方向が一定な とき, 各指力の大きさの変化によってそれらの合力は集合 $\boldsymbol{T}_{\boldsymbol{f}}$ の領域内において変動する。

式 (27) と式（13）によって, 多指ハンドの多点把持で実現 できる環境への押し付け力の集合は, 各指力からなる合力の集 合と接触状態における押し付け力の集合との共通集合として,

$$
\boldsymbol{F}_{t}=\boldsymbol{T}_{f} \cap \widehat{\boldsymbol{F}}_{E^{\prime}}=\left\{\boldsymbol{H}_{t} \boldsymbol{k}_{t} \mid \boldsymbol{k}_{t}>\mathbf{0}\right\}
$$

のように得られる.ただし， $\widehat{\boldsymbol{F}}_{E^{\prime}}$ が式 (14)により記述される場 


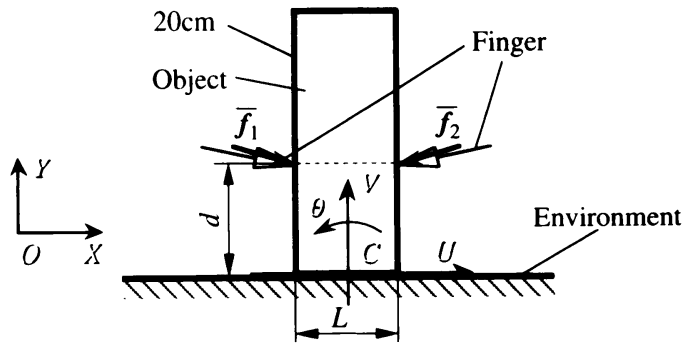

Fig. 9 Example for evaluating the grasping position

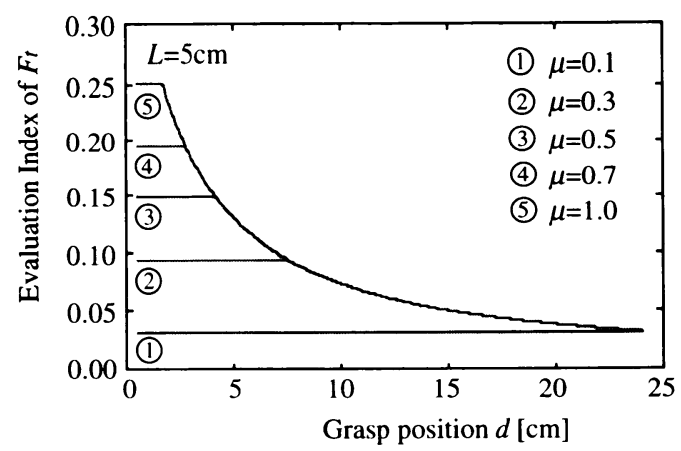

Fig. 10 Result when $L=5[\mathrm{~cm}]$ but $d$ is variable

合には $\boldsymbol{F}_{t}=\boldsymbol{T}_{f} \cap\left\{\bigcup_{j=1}^{u} \widehat{\boldsymbol{F}}_{E^{\prime}{ }_{j}}\right\}=\bigcup_{j=1}^{u}\left\{\boldsymbol{H}_{t j} \boldsymbol{k}_{t j} \mid \boldsymbol{k}_{t j}>\mathbf{0}\right\}$ となる。 $\boldsymbol{F}_{t}$ の領域が大きいほど指力大きさの変化可能な領域 が大きくなり，対象物と環境の接触の実現とその維持がより安 易に行える．領域の評価指標を用いて $\boldsymbol{F}_{t}$ の領域評価を行うと， 多指ハンドの把持位置を評価できる。

\subsection{2 指の把持位置への評価の例}

Fig. 9 の平面内運動の例を考える. 対象物上の把持位置 $d$, 対象物と環境との接触部の長さ $L$, またその接触部の異なる 摩擦条件により，方向が一定な指先力から実現可能な押し付け 力の領域が異なることを示す。ここで物体間の静止摩擦係数を $0.1 ， 0.3,0.5,0.7,1.0$ とし, 両指先力の方向をそれぞれ $\bar{f}_{1}$ $=[3 / \sqrt{10},-1 / \sqrt{10}]^{T}, \overline{\boldsymbol{f}}_{2}=[-3 / \sqrt{10},-1 / \sqrt{10}]^{T}$ とする.

計算結果として, 接触部 $L$ が一定な場合の把持位置 $d$ に従 j $\boldsymbol{F}_{t}$ の評価指標の変化と, 静止摩擦係数が一定な場合の把持 位置 $d$ に従う $\boldsymbol{F}_{t}$ の評価指標の変化とは，それぞれ Fig. 10 と Fig. 11 に示されている.ただし $\boldsymbol{F}_{t}$ は二次元空間に存在する. これらの結果によって，対象物上の把持位置 $d$ が大きいほど $\boldsymbol{F}_{t}$ の評価指標が小さくなる傾向がある。例えば， $L=5[\mathrm{~cm}]$, $\mu=0.5$ について, $d=3[\mathrm{~cm}]$ のとき, 評価指標は 0.148 であ るが, $d=8[\mathrm{~cm}]$ のとき 0.088 となり，さらに $d=13[\mathrm{~cm}]$ と するとその評価指標は 0.057 となる，参照のため，指力の大き さの変化範囲を $0 \sim 1$ のように設定すると, $d=3[\mathrm{~cm}], 8[\mathrm{~cm}]$, $13[\mathrm{~cm}]$ に対応する指力大きさ変化の許容範囲はそれぞれ 0.58 $0.81 ， 0.64 \sim 0.77 ， 0.66 \sim 0.74$ となる.よって，一定の押し付 け力で環境との接触をより安易に実現して維持したいとき，対 象物の下の部分を把持すればよいと判断される。こ机は直感に かなったものと一致している。ただし，ここでは不確実な外乱 に直接抵抗する指力を能動的に発生させることは考えていない.

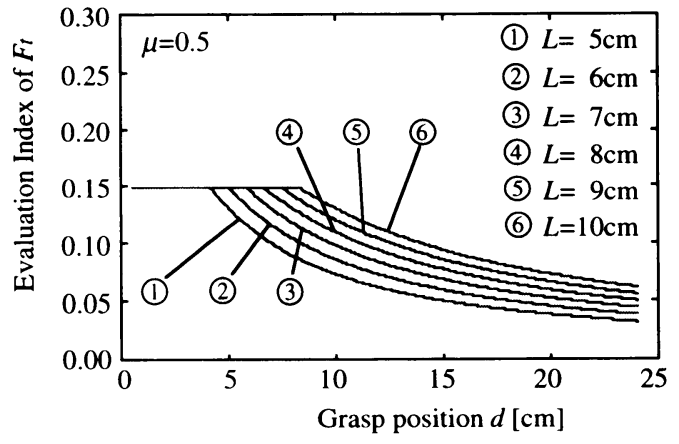

Fig. 11 Result when $\mu=0.5$ but $d$ is variable

\section{5. 結言}

物体どうしが接触しているとき，対象物体が受けた幾何拘束 の領域, 接触力の可能領域抽よび物体変位の可能領域をそれぞ れ凸多面錐で記述することができる．組立操作などの計画にお いて, 操作途中のおのおのの可能な接触状態の内, 安定性のよ い接触をもつ状態を選ぶことが望ましい，幾何拘束領域や接触 力領域が大きければ大きいほど，その接触の安定性がよいと考 えられる，本論文では，高次元空間における凸多面錐に対し，部 分単位超球を導入してその部分超球面積により凸多面錐の領域 を量的に評価する方法を提案した．まず，接触を受ける対象物 の可能微小変位の集合，対象物への形態拘束方向の集合および 環境への押し付け力の集合について述べ, 接触物体間の運動学 的力学的関係を記述した。ついで, 単位超球面上において各集 合の領域を表現し，対応する超球面積により領域大きさの評価 指標を提案した。そして，その組立作業計画への応用について 述べ，数值例によって有効性を示した。

\section{参 考 文 献}

[1] M.S. Ohwovoriole and B. Roth: "An Extension of Screw Theory," Journal of Mechanical Design, vol.103, no.10, pp.725-735, 1981

[2] S. Hirai and H. Asada: "Kinematics and Statics of Manipulation Using the Theory of Polyhedral Convex Cones," The International Journal of Robotics Research, vol.12, no.5, pp.434$447,1993$.

[3] J.C. Trinkle and R.P. Paul: "Planning for Dexterous Manipulation with Sliding Contacts," The International Journal of Robotics Research. vol.9, no.3, pp.24-48, 1990.

[4] J.M. Schimmels and M.A. Peshkin: "Admittance Matrix Design for Force-Guided Assembly," IEEE Transactions on Robotics and Automation, vol.8, no.2, pp.213-226, 1992.

[5] K. Lakshminarayana: "Mechanics of Form Closure," ASME Report, 78-DET-32, 1978.

[6] J. Kerr and B. Roth: "Analysis of Multifingered Hands," The International Journal of Robotics Research, vol.4, no.4, pp.3$17,1986$.

[7] 布川, 中山, 欲野: 線形代数と凸解析. pp.125-187, コロナ社, 1991 .

[8] 比留川, 松井, 高瀬：“多面体間の接触による拘束条件を幾何モデル から導出する一般的なアルゴリズム”，日本ロボット学会誌，vol.9， no.4, pp.415-426, 1991.

[9] 張, 中村, 吉本：“不完全な接触をもつ把持の力学的多面凸解析”, 日 本ロボット学会誌, vol.14, no.1, pp.105-113, 1997.

[10] 古川：“把持と操りの基礎理論 1. 受動拘束と能動拘束”, 日本ロボッ 卜学会誌, vol.13, no.7, pp.950-957, 1995. 
[11] 吉川, 横小路, 余：“拘束状態遷移難度に基づくロボットによる組立作業 の計画法”，システム制御情報学会論文誌，vol.5, no.7, pp.283-293, 1992.

[12] 余, 横小路, 吉川：“接触状態に扔ける二種類の自由度の定義とその 組立作業計画への応用”, システム制御情報学会論文誌, vol.8, no.2, pp.80-90, 1995.

[13] 余, 横小路, 中須, 吉川: “複数のロボット指による環境と接触している
物体の準動的操作”, 日本ロボット学会誌, vol.13, no.6, pp.875-885, 1995.

[14] 余, 竹内, 吉川：“ロボットハンドによるパワーグラスプの最適化”, 日本ロボット学会誌, vol.17, no.4, pp.557-566, 1999.

[15] Y. Yu and T. Yoshikawa: "Evaluation of Contact Stability between Objects," Proc. of IEEE Int. Conf. on Robotics and Automation, vol.1, pp.695-702, Apr. 1997.

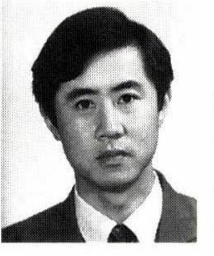

余永 (Yong Yu)

1957 年 1 月 29 日生. 1991 年京都大学大学院工学 研究科博士前期課程修了, 1995 年同大学大学院工 学研究科博士後期課程修了. 鹿児島大学工学部機械 工学科講師を経て，1999 年同助教授となり現在に 至る。ロボットによる組立作業の自動計画, 複数口 ボット機構の協調，アクティブセンシングなどに興 味を持つ. 博士 (工学). システム制御情報学会, 米国 IEEE 学会な どの会員.

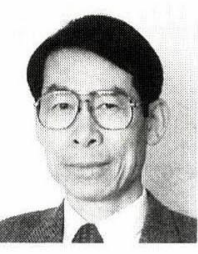

吉川恒夫 (Tsuneo Yoshikawa)

1941 年 12 月 19 日生. 1964 年京都大学工学部精密 工学科卒業, 1969 年同大学大学院工学研究科博士課 程修了, 同大学工学部助手, 1970 年同助教授, 1986 年同教授 (オートメーション研究施設, 1989 91 年応用システム科学教室, 1991 年より機械工学教 室). 1994 年組織変更により, 同大学大学院工学研 究科教授（機械工学専攻）となり現在に至る。その間 1973１975 年 米国 NASA マーシャル宇宙飛行センターNRC 隼研究員.ロボット工 学, メカトロニクス, 制御工学の研究に従事. 工学博士. システム制 御情報学会, 日本機械学会, 計測自動制御学会, 日本バーチャルリア リティ学会, 米国 IEEE 学会などの会員. (日本ロボット学会正会員) 